\title{
Towards the diversity of non-biting midges of the tribe Tanytarsini from Eocene Baltic amber (Diptera: Chironomidae)
}

\author{
Marta Zakrzewska, Wiesław Krzemiński, and Wojciech Giłka
}

\begin{abstract}
This work is a systematic study of non-biting midges (Chironomidae) of the tribe Tanytarsini found in Baltic amber (Gulf of Gdańsk, $\sim 40-45 \mathrm{Ma}$ ) collected by C. and H.W. Hoffeins, Hamburg, Germany. Given the rarity of Tanytarsini species/specimens so far recorded in Eocene ambers of the Baltic region, known from 17 species in eight genera, the Hoffeins collection is distinguished by its relatively high diversity. Among chironomid specimens collected, 39 Tanytarsini adult males were found, including 28 individuals studied in detail. They belong to 12 species from seven genera, including three new species. Rheotanytarsus hoffeinsorum sp. nov. is the second known Eocene species of the genus. Tanytarsus crocota sp. nov. and Stempellinella fibra sp. nov. display sets of unique characters in these genera. Emended diagnoses of Archistempellina falcifera Giłka and Zakrzewska, 2013 and A. perkovskyi Giłka and Zakrzewska, 2014, hitherto known from single individuals, and morphological variability in selected Eocene species of the genus Tanytarsus van der Wulp, 1874, are also presented. As a synthesis of our work and comparisons achieved in order to define the taxa studied, a key to the identification of all Eocene Tanytarsini genera (8) and species (20) known from Baltic amber is provided.
\end{abstract}

Marta Zakrzewska. Department of Invertebrate Zoology and Parasitology, University of Gdańsk, Wita Stwosza 59, 80-308 Gdańsk, Poland. marta.zakrzewska@biol.ug.edu.pl

Wiesław Krzemiński. Institute of Systematic and Evolution of Animals, Polish Academy of Sciences, Sławkowska 17, 31-016 raków, Poland. krzeminski@muzeum.pan.krakow.pl

Wojciech Giłka. Department of Invertebrate Zoology and Parasitology, University of Gdańsk

Wita Stwosza 59, 80-308 Gdańsk, Poland. wojciech.gilka@biol.ug.edu.pl (corresponding author).

Keywords: Baltic amber; Chironomidae; Tanytarsini; systematics; new species; key

Submission: 21 December 2015 Acceptance: 2 May 2016

http://zoobank.org/BAA44C0D-C497-4CED-85D7-B74A2A2AAEB4

Zakrzewska, Marta, Krzemiński, Wiesław, and Giłka, Wojciech. 2016. Towards the diversity of non-biting midges of the tribe Tanytarsini from Eocene Baltic amber (Diptera: Chironomidae). Palaeontologia Electronica 19.2.18A: 1-21 palaeo-electronica.org/content/2016/1434-tanytarsini-in-baltic-amber

Copyright: Palaeontological Association June 2016 


\section{INTRODUCTION}

When the number of species described and the complex systematic division are taken into account, the Chironomidae (over 7,000 species in more than 500 genera and 12 subfamilies) is undoubtedly the most diverse group of aquatic dipterans (Pape et al., 2011). This family has left fossil records since the Late Triassic (Krzemiński and Jarzembowski, 1999) with most taxa described from Eocene ambers. The fossil chironomid fauna found in amber from the Baltic region is the best studied one, including the so far oldest known members of the Tanytarsini - the tribe within the second largest subfamily Chironominae (Seredszus and Wichard, 2007; Giłka, 2010, 2011a; Giłka et al., 2013; Zakrzewska and Giłka, 2013, 2014, 2015a, 2015b). According to the current division, the oldest Eocene Tanytarsini are represented by genera classified in two known subtribes: Tanytarsina (see couplets 10-17 in a key given below) and Zavreliina (couplets 18-21), with the exception of the extinct genera with unexplained subtribal position (couplets 3-9) (Zakrzewska and Giłka, 2014, 2015b). Evolutionary trends based on the fossils record of Eocene Tanytarsini were recently discussed by Zakrzewska and Giłka (2014, 2015a, 2015b), whereas the higher level internal relationships within the Chironomidae, including the Chironominae and Tanytarsini, and their dating based on molecular analyses were presented by Cranston et al. (2012).

In contrast to extant Tanytarsini, which make up approximately $10 \%$ of the known species of Chironomidae, fossil representatives of this tribe are relatively rarely encountered in Eocene resins of the Baltic region. The latest data, based on examinations of a collection of Baltic amber comprising more than 15,000 animal inclusions, indicate that Tanytarsini account for ca. $3 \%$ of all the chironomid specimens and less than $0.3 \%$ of the zooinclusions (Zakrzewska and Giłka, 2015a).

The presently studied material is a small part of the private collection of amber inclusions of Christel and Hans Werner Hoffeins (Hamburg, Germany). The collection, established in the beginning of 1980, is focused on animal inclusions in Baltic amber originating from the shore of the Baltic Sea and from Bitterfeld coal. This collection comprises thousands of specimens (ca. 23,000 insect individuals, including nearly 9,500 dipterans), among them the holotypes of seven plant and 169 animal species, including 59 holotypes of Diptera (C. Hoffeins, personal commun., 2015). Some of the most valuable are Nymphomyia succina Wag- ner et al., 2000 (Nymphomyiidae) - the first fossil record of this archaic family, and Protanthomyia minuta Michelsen, 2000 (Anthomyiidae) - the first and only calyptrate fly found in Eocene amber (Michelsen, 2000; Wagner et al., 2000). The first record of a carnivorous plant from the family Roridulaceae was also based on a sample (leaves) from the Hoffeins collection (Sadowski et al., 2015). Non-biting midges from this collection are represented by over 1,800 specimens (ca. $20 \%$ of dipteran inclusions): nearly 1,000 from the Bitterfeld and over 800 from the Gulf of Gdańsk; however, many of them remain identified only to the family level or taxa of higher rank within the Chironomidae (C. Hoffeins, personal commun., 2015). Ambers from these deposits, along with that sourced from the Rovno region are proposed to be treated as one, here called "Baltic amber" (Szwedo and Sontag, 2013).

Our work, based on the Tanytarsini inclusions from the Hoffeins collection, all sourced from the Gulf of Gdańsk, revealed a surprisingly high diversity: 12 species from seven genera, including three new species. As a result, the number of all known Eocene Tanytarsini has risen to 20 species in eight genera (cf. Zakrzewska and Giłka, 2015a, 2015b) all the taxa included in a key to their identification presented below.

\section{MATERIALS AND METHODS}

In this study 39 Tanytarsini individuals were examined, all as inclusions in Baltic amber collected from the Gulf of Gdańsk, of which 28 specimens are sufficiently well-preserved to be accurately identified and/or described (Table 1). The amber was cut into small pieces, ground, and polished manually (Figure 1). Measurements of specimens are in $\mu \mathrm{m}$, except for the total length (in $\mathrm{mm}$, rounded off to the first decimal place). The body was measured from the antennal pedicel to the end of the gonostylus, and the wing from the arculus to the tip. Lengths of leg segments and palpomeres were rounded off to the nearest 5 and 1 $\mu \mathrm{m}$, respectively. The antennal, leg, and venarum ratios (AR, LR, VR) were calculated to the second decimal place. The morphological terminology and abbreviations follow Sæther (1980). The photographs were taken using the classic microscope PZO Biolar SK14 and Helicon Focus 6 image stacking software. All the specimens described in this manuscript are part of the collection of Christel and Hans Werner Hoffeins, and are booked to be deposited at the Senckenberg Deutsches Entomologisches Institut, Müncheberg, Germany (Table 1). 
TABLE 1. Species of the tribe Tanytarsini in the Hoffeins collection and inventory numbers of amber pieces with the specimens examined. $\mathrm{CCHH}=$ the collection of Christel and Hans Werner Hoffeins, Germany.

\begin{tabular}{|c|c|c|}
\hline Species & Specimen & Inventory number \\
\hline Archistempellina falcifera & 10 & $\mathrm{CCHH} 257-1$ \\
\hline Archistempellina perkovskyi & $1 \hat{0}$ & $\mathrm{CCHH} 1754-4$ \\
\hline Caladomyia szadziewskii & $1 \delta$ & $\mathrm{CCHH} 213-3$ \\
\hline Corneliola avia & $5 \lesssim ð$ & $\mathrm{CCHH} 93-8, \mathrm{CCHH} 213-6, \mathrm{CCHH} 242-7, \mathrm{CCHH} 257-4, \mathrm{CCHH} 1754-9$ \\
\hline Eonandeva helva & 13 & $\mathrm{CCHH} 1754-1$ \\
\hline Eonandeva latistyla & $1 \delta$ & $\mathrm{CCHH} 1754-10$ \\
\hline Rheotanytarsus hoffeinsorum & $1 \delta$ & $\mathrm{CCHH} 242-6$ \\
\hline Stempellinella fibra & $1 \delta^{\lambda}$ & $\mathrm{CCHH} 257-5$ \\
\hline Tanytarsus crocota & $1 \delta$ & $\mathrm{CCHH} 1754-7$ \\
\hline Tanytarsus glaesarius & 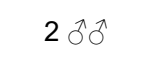 & $\mathrm{CCHH} 213-4$ \\
\hline Tanytarsus protogregarius & $5 \widehat{\partial}$ & CCHH 242-1, CCHH 242-11, CCHH 257-8, CCHH 1754-12 \\
\hline Tanytarsus serafini & 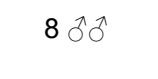 & $\begin{array}{c}\text { CCHH 93-7, CCHH 213-9, CCHH 242-2, CCHH 242-3, CCHH 257-9, } \\
\text { CCHH 1754-2, CCHH 1754-3, СCHH 1754-8 }\end{array}$ \\
\hline Tanytarsini indet. & $11 \lesssim ð$ & $\begin{array}{c}\mathrm{CCHH} \text { 93-9, CCHH 140-6, CCHH 213-1, CCHH 213-2, CCHH 213-8, } \\
\mathrm{CCHH} 242-8, \mathrm{CCHH} 257-7, \mathrm{CCHH} 257-3, \mathrm{CCHH} 242-9, \mathrm{CCHH} 242-12,\end{array}$ \\
\hline
\end{tabular}
$\mathrm{CCHH}$ 1754-13A

\section{RESULTS}

\section{Systematic Palaeontology}

Family CHIRONOMIDAE Newman, 1834

Subfamily CHIRONOMINAE Newman, 1834 Tribe TANYTARSINI Zavřel, 1917

Extinct genera. The subtribal position of the recently described fossil genera Archistempellina Giłka and Zakrzewska in Giłka, Zakrzewska, Dominiak and Urbanek, 2013, Corneliola Giłka and Zakrzewska in Giłka, Zakrzewska, Dominiak and Urbanek, 2013 and Eonandeva Giłka and Zakrzewska in Zakrzewska and Giłka, 2015b has not been definitively determined. Here, following the concept based on adult morphology and characters examinable in fossil individuals, in particular the wing venation pattern, shape, and chaetotaxy, we present these genera as possible stem lineages of the subtribe Zavreliina or the entire tribe Tanytarsini (Giłka et al., 2013; Zakrzewska and Giłka, 2014, 2015b).

\section{Genus ARCHISTEMPELLINA \\ Giłka and Zakrzewska, 2013}

Type species. Archistempellina bifurca Giłka and Zakrzewska in Giłka, Zakrzewska, Dominiak and Urbanek, 2013 (original designation).

\section{Archistempellina falcifera}

Giłka and Zakrzewska, 2013

Figure 1
2013 Archistempellina falcifera Giłka and Zakrzewska in Giłka et al., p. 573, figure 2 (male).

2014 Archistempellina falcifera Giłka and Zakrzewska in Zakrzewska and Giłka, p. 342 (in key).

Material examined. Adult male (tarsi of right mid and left hind legs missing) in $20.5 \times 7.5 \times 6.5 \mathrm{~mm}$ piece of amber (Eocene, 40-45 Ma, Gulf of Gdańsk; CCHH 257-1, Figure 1); animal syninclusions: Orthocladiinae (1 female), Aphidodea (1 ind.).

Remarks. The recently established genus Archistempellina is known from three species described on the basis of amber inclusions collected from the Rovno region, two of which are also present in the Hoffeins collection of amber from the Gulf of Gdańsk. Based on the specimen presently examined, the original description of Archistempellina falcifera is thus supplemented with the following characters: wing length $1460 \mu \mathrm{m}, \mathrm{VR}_{\mathrm{Cu}}$ 1.27; thorax chaetotaxy: Ac at least 24, Dc at least 17-18 on each side, $\mathrm{Pa}$ 3-4 on each side, Sc at least 10; fore leg tibia bearing a single spur along with strong subapical bristles. Measurements of leg segments and leg ratios are compiled with those taken from the holotype specimen in Table 2.

\section{Archistempellina perkovskyi}

Giłka and Zakrzewska, 2014

Figure 1 


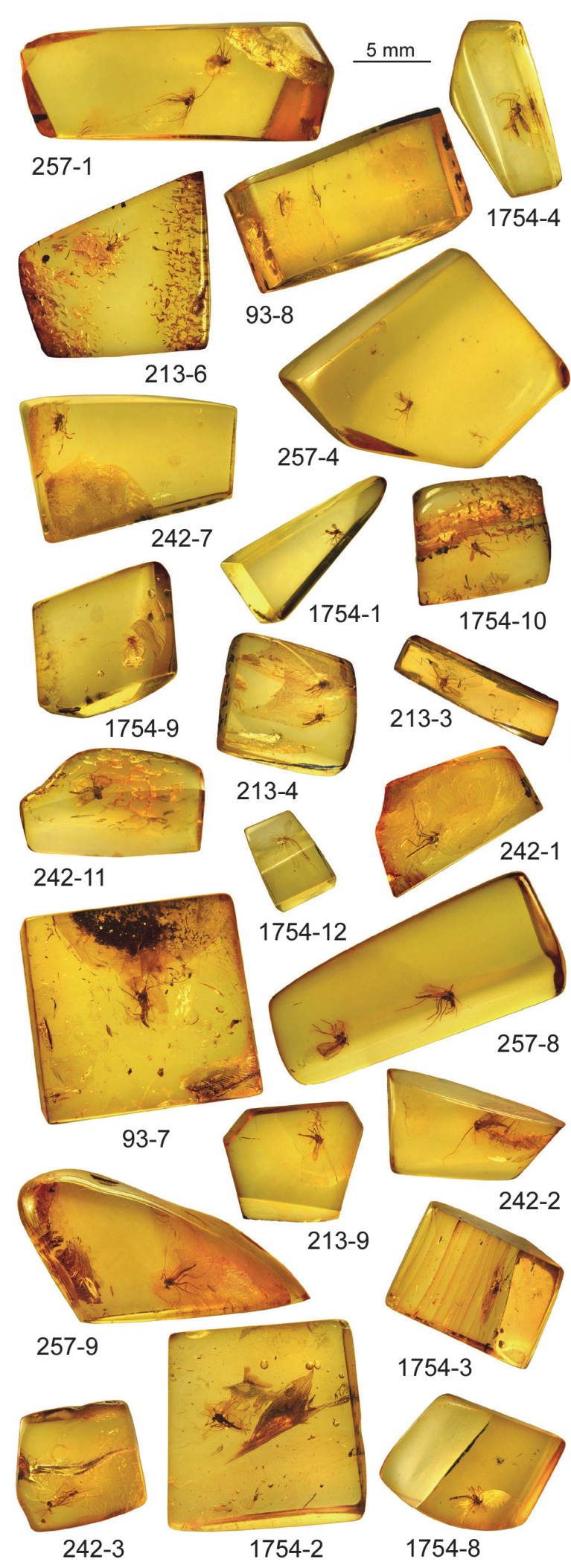

FIGURE 1. Tanytarsini - inclusions in Baltic amber from the Hoffeins collection (for details see Table 1 and Material examined).
2014 Archistempellina perkovskyi Giłka and Zakrzewska in Zakrzewska and Giłka, p. 336, 342 (male, in key), figures $1,2$.

Material examined. Adult male (complete specimen) in $11.5 \times 6 \times 3.5 \mathrm{~mm}$ piece of amber (Eocene, 40-45 Ma, Gulf of Gdańsk; CCHH 1754-4, Figure 1).

Remarks. Archistempellina perkovskyi is a unique species known from the adult male, which bears distinct semicircular posterolateral lobes on the hypopygial tergite (see Zakrzewska and Giłka, 2014). We assume that these unusual structures can be incorrectly recognized as lobes of the superior volsellae, thus we confirm them as parts of the tergite (well developed in the examined specimen), probably homologous with those called "shoulders" (e.g., Ekrem et al., 2003). The original description of $A$. perkovskyi should be also supplemented with the following characters: wing length $1245 \mu \mathrm{m}$, $\mathrm{VR}_{\mathrm{Cu}}$ 1.28; clypeus with at least 12 setae; thorax chaetotaxy: Ac at least 14, Dc at least 11-13, Pa 3, Scts at least 12; hind leg tibia with at least one spur ca. $45 \mu \mathrm{m}$ long. Measurements of leg segments and leg ratios are compiled with those taken from the holotype specimen in Table 3. Unfortunately, some characters are still impossible to define on the basis of the presently examined male trapped in resin as freshly emerged (AR unmeasurable, hypopygium sunk into the abdomen with the anal point reaching the mid length of the inferior volsellae).

Genus CORNELIOLA Giłka and Zakrzewska, 2013

Type species. Corneliola avia Giłka and Zakrzewska in Giłka, Zakrzewska, Dominiak and Urbanek, 2013 (original designation and monotypy).

\section{Corneliola avia \\ Giłka and Zakrzewska, 2013}

Figure 1

2013 Corneliola avia Giłka and Zakrzewska in Giłka et al.: 575, figures 3-5 (male, female).

2014 Corneliola avia Giłka and Zakrzewska in Zakrzewska and Giłka: 342 (male, in key).

2015a Corneliola avia Giłka and Zakrzewska in Zakrzewska and Giłka: 348 (remarks), figure 2.

Material examined. Five adult males in 5 pieces of amber (Eocene, 40-45 Ma, Gulf of Gdańsk, Figure 1): 1 male $(\mathrm{CCHH} 93-8,15 \times 7.5 \times 6.5 \mathrm{~mm}) ; 1$ male $(\mathrm{CCHH} 213-6,12.5 \times 11.5 \times 3 \mathrm{~mm}) ; 1$ male (CCHH 242-7, $14 \times 9 \times 4 \mathrm{~mm})$, animal syninclusions: Acari (2 ind.); 1 male (CCHH 257-4, $15 x$ $12.5 \times 7.5 \mathrm{~mm}$ ), animal syninclusion: Acari (1 ind.); 1 male $(\mathrm{CCHH} 1754-9,9.5 \times 8 \times 4 \mathrm{~mm})$. 
TABLE 2. Leg segment lengths $(\mu \mathrm{m})$ and leg ratios of male Archistempellina falcifera. Measurements of the holotype are in bold (cf. Giłka et al., 2013). $p_{1}-p_{3}=$ pair of legs 1-3, fe=femur, ti=tibia, ta ta $_{5}=$ tarsomeres $1-5$, LR=leg ratio.

\begin{tabular}{ccccccccc}
\hline & $\mathbf{f e}$ & $\mathbf{t i}$ & $\mathbf{t a}_{1}$ & $\mathbf{t a}_{2}$ & $\mathbf{t a}_{3}$ & $\mathbf{t a}_{4}$ & $\mathbf{t a}_{5}$ & LR \\
\hline $\mathrm{p}_{1}$ & - & $440-500$ & $895-960$ & $460-480$ & $380-400$ & $290-305$ & $120(\mathbf{1 2 0})$ & $\mathbf{1 . 9 2 - 2 . 0 3}$ \\
$\mathrm{p}_{2}$ & $\mathbf{8 2 5}$ & $610-\mathbf{6 4 5}$ & $455-460$ & 230 & 185 & 125 & 80 & $\mathbf{0 . 7 1 - 0 . 7 5}$ \\
$\mathrm{p}_{3}$ & $\mathbf{7 8 0}$ & $660-750$ & 615 & - & - & - & - & 0.93 \\
\hline
\end{tabular}

TABLE 3. Leg segment lengths $(\mu \mathrm{m})$ and leg ratios of male Archistempellina perkovskyi. Measurements of the holotype are in bold (cf. Zakrzewska and Giłka, 2014). $p_{1}-p_{3}=$ pair of legs 1-3, fe=femur, ti=tibia, ta -ta $_{5}=$ tarsomeres $1-5$, $L R=$ leg ratio.

\begin{tabular}{ccccccccc}
\hline & $\mathbf{f e}$ & $\mathbf{t i}$ & $\mathbf{t a}_{1}$ & $\mathbf{t a}_{2}$ & $\mathbf{t a}_{3}$ & $\mathbf{t a}_{4}$ & $\mathbf{t a}_{5}$ & LR \\
\hline $\mathrm{p}_{1}$ & 675 & 395 & 795 & 430 & 355 & 270 & 105 & 2.01 \\
$\mathrm{p}_{2}$ & $675-\mathbf{7 5 0}$ & $550-630$ & 380 & 210 & 165 & 105 & 65 & 0.69 \\
$\mathrm{p}_{3}$ & 675 & $605-\mathbf{7 3 0}$ & $505-585$ & $305-345$ & $255-275$ & $150-165$ & $\mathbf{7 0 - 7 5}$ & $\mathbf{0 . 8 0 - 0 . 8 3}$ \\
\hline
\end{tabular}

Remarks. This is one of the most frequent Tanytarsini species in Baltic amber collected both from the Gulf of Gdańsk and the Rovno region (Giłka et al., 2013; Zakrzewska and Giłka, 2015a), and the only fossil species of this tribe known from the adult female.

\section{Genus EONANDEVA}

Giłka and Zakrzewska, 2015

Type species. Eonandeva helva Giłka and Zakrzewska in Zakrzewska and Giłka, 2015b (original designation).

\section{Eonandeva helva \\ Giłka and Zakrzewska, 2015}

Figure 1

2015b Eonandeva helva Giłka and Zakrzewska in Zakrzewska and Giłka, p. 578, figures 1, 2 (male).

Material examined. Holotype. Adult male (tarsi of all legs missing) preserved in $12 \times 5 \times 4 \mathrm{~mm}$ piece of amber (Eocene, 40-45 Ma, Gulf of Gdańsk; $\mathrm{CCHH}$ 1754-1; Figure 1).

\section{Eonandeva latistyla}

Giłka and Zakrzewska, 2015

\section{Figure 1}

2015b Eonandeva latistyla Giłka and Zakrzewska in Zakrzewska and Giłka, p. 581, figures 3, 4 (male).

Material examined. Holotype. Adult male (tarsi of left mid and hind legs missing) preserved in $8.5 \mathrm{x}$ $7.5 \times 3.5 \mathrm{~mm}$ piece of amber (Eocene, $440-45 \mathrm{Ma}$, Gulf of Gdańsk; CCHH 1754-10; Figure 1).

Remarks. A systematic concept for the recently erected genus Eonandeva, with remarks on phylogeny was presented by Zakrzewska and Giłka (2015b). For the hypopygial and wing characters best separating Eonandeva helva and E. latistyla see the specific diagnoses (op. cit.) and the key (below).

Subtribe TANYTARSINA Zavřel, 1917

Genus CALADOMYIA Säwedal, 1981

Type species. Caladomyia spixi SÄWEDAL, 1981 (original designation).

$$
\begin{aligned}
& \text { Caladomyia szadziewskii } \\
& \text { Giłka and Zakrzewska, } 2013
\end{aligned}
$$

\section{Figure 1}

2013 Caladomyia szadziewskii Giłka and Zakrzewska in Zakrzewska and Giłka, p. 398, figures 1, 2 (male).

2014 Caladomyia szadziewskii Giłka and Zakrzewska in Zakrzewska and Giłka, p. 342 (in key).

Material examined. Holotype. Adult male (right fore leg missing) in $11 \times 3 \times 3 \mathrm{~mm}$ piece of amber (Eocene, 40-45 Ma, Gulf of Gdańsk; CCHH 2133, Figure 1).

Remarks. This species was described in detail by Zakrzewska and Giłka (2013) based on the only known specimen from the Hoffeins collection.

$$
\text { Genus RHEOTANYTARSUS }
$$

Thienemann and Bause in Bause, 1913

Type species. Tanytarsus pentapoda Kieffer, 1909 (designation: Goetghebuer in Goetghebuer and Lenz, 1954).

Rheotanytarsus hoffeinsorum

Giłka, Zakrzewska and Krzemiński sp. nov. Figures 2, 3

zoobank.org/45416C6E-B107-40B0-87BA-052F53F0249E

Type material. Holotype. Adult male (tarsi of fore and mid legs missing, wings damaged in part) preserved in $9 \times 9 \times 3.5 \mathrm{~mm}$ piece of amber (Eocene, 40-45 Ma, Gulf of Gdańsk; CCHH 242-6; Figure 


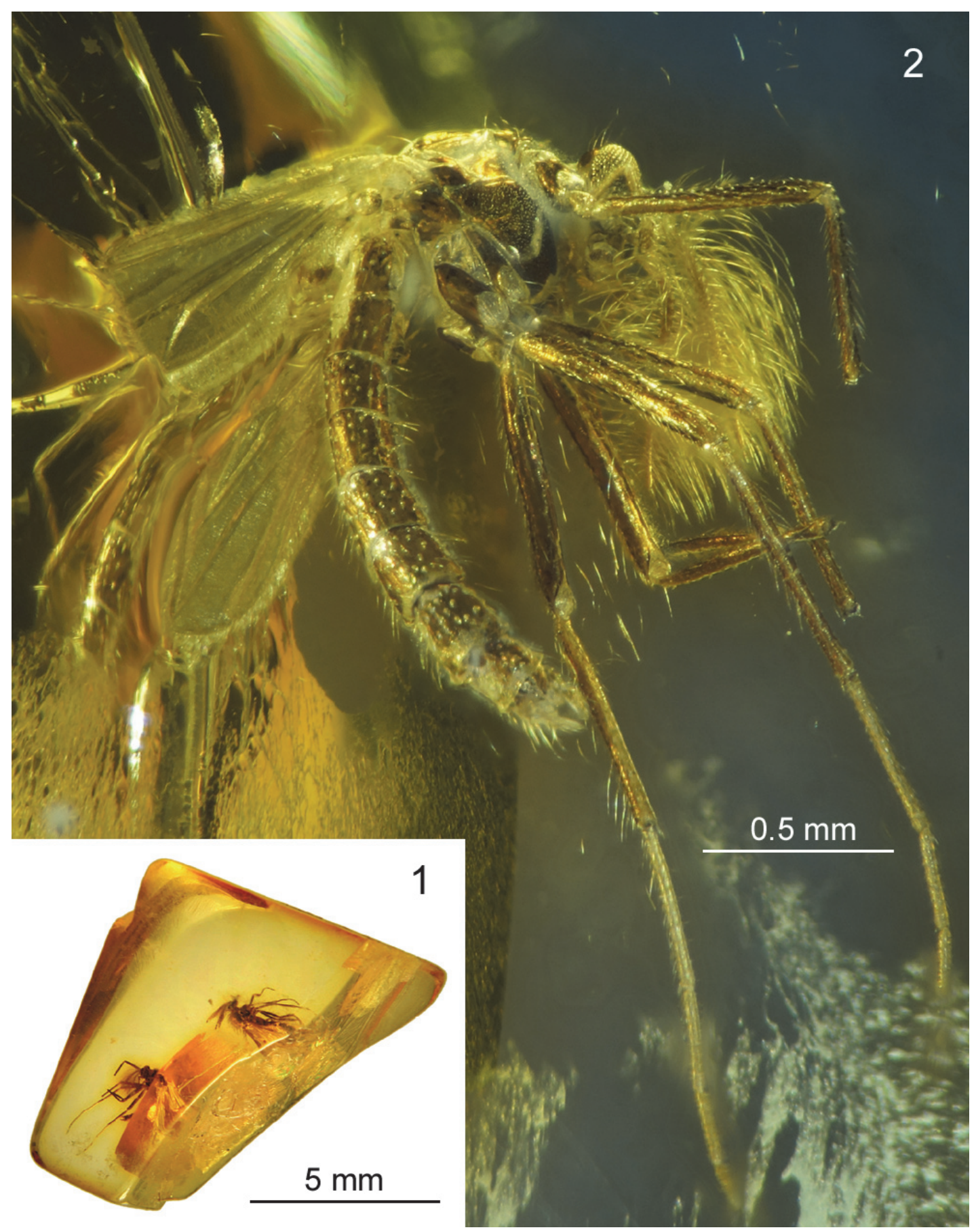

FIGURE 2. Rheotanytarsus hoffeinsorum sp. nov., adult male, holotype. 1, as syninclusion in amber (at left); 2 , habitus.

2.1); animal syninclusion: Ceratopogonidae (1 male).

Derivation of the name. The specific epithet honours Christel and Hans Werner Hoffeins in commemoration of their contribution to the study of fossil insects.
Diagnosis. Gonostylus stout, slightly narrowed in distal part. Anal tergite with distinct round field bearing strong median setae. Anal point long, narrowed in mid length, broadened in distal part, with swollen apex. Superior volsella reniform, with posteriorly directed rounded apex. Stem of median vol- 

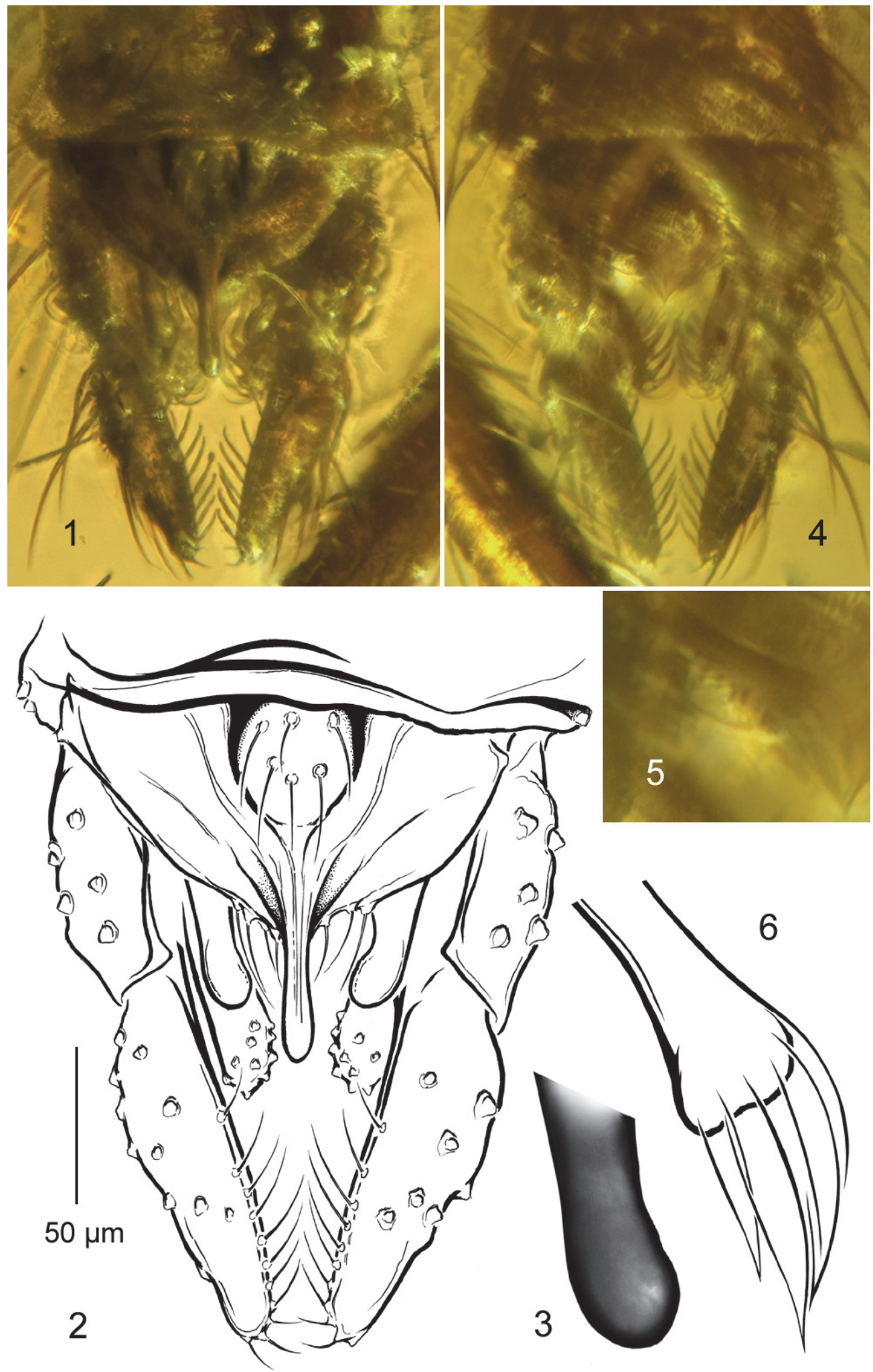

FIGURE 3. Rheotanytarsus hoffeinsorum sp. nov., adult male, holotype. Hypopygium and its structures in dorsal (1-3) and ventral aspect (4-6), photographed in reflected light $(\mathbf{1}, \mathbf{4}, \mathbf{5})$ and drawn $(\mathbf{2}, \mathbf{3}, \mathbf{6}) ; \mathbf{3}$, superior volsella; 5-6, median volsella (6 magnified ca. 2 times relative to 5 and ca. 5 times relative to 4 ). 
TABLE 4. Leg segment lengths $(\mu \mathrm{m})$ and leg ratios of male Rheotanytarsus hoffeinsorum $\mathrm{sp}$. nov. $\mathrm{p}_{1}-\mathrm{p}_{3}=$ pair of legs $1-$ 3 , fe=femur, ti=tibia, $\mathrm{ta}_{1}$-ta ${ }_{5}=$ tarsomeres $1-5, \mathrm{LR}=$ leg ratio.

\begin{tabular}{ccccccccc}
\hline & $\mathbf{f e}$ & $\mathbf{t i}$ & $\mathbf{t a}_{1}$ & $\mathbf{t a}_{2}$ & $\mathbf{t a}_{3}$ & $\mathbf{t a}_{4}$ & $\mathbf{t a}_{5}$ & $\mathbf{L R}$ \\
\hline $\mathrm{p}_{1}$ & 690 & 515 & - & - & - & - & - & - \\
$\mathrm{p}_{2}$ & 750 & 625 & - & - & - & - & - & - \\
$\mathrm{p}_{3}$ & 765 & 720 & 470 & 275 & 220 & 140 & 100 & 0.65 \\
\hline
\end{tabular}

sella bone-shaped, ca. $25 \mu \mathrm{m}$ long, with 4 leafshaped separate lamellae.

Description. Adult male $(n=1)$.

Total length ca. $2.5 \mathrm{~mm}$.

Head (Figure 2.2). Eyes bare, with well-developed dorsomedian extensions. Frontal tubercles absent. Antenna with 13 flagellomeres, AR ca. 0.95 . Length of palpomeres 2-5 ( $\mu \mathrm{m})$ : 32, 113, 145, 213. Clypeus with at least 13 setae.

Thorax chaetotaxy. Ac at least 9; Dc at least 7, Pa 4, Scts at least 14.

Wing. Observable parts of the wing typical for Tanytarsini and Rheotanytarsus, apices of wings and chaetotaxy unobservable (Figure 2.2).

Legs. Spur of fore leg tibia not observed. Mid and hind leg tibia with 2 separated combs, teeth length up to $20 \mu \mathrm{m}$ (mid leg) and $30 \mu \mathrm{m}$ (hind leg); each comb bearing spur, ca. $45 \mu \mathrm{m}$ long (mid leg) and ca. $50 \mu \mathrm{m}$ long (hind leg). For length of leg segments and leg ratio see Table 4.

Hypopygium (Figure 3). Gonostylus stout, ca. 120 $\mu \mathrm{m}$ long, longer than gonocoxite, broadest near base, slightly narrowed in distal part, apex widely rounded, with row of strong setae on median margin in distal half. Anal tergite semicircular, with distinct round field bearing strong median setae. Anal point typical of the genus, long, narrowed in mid length, broadened in distal part, with swollen apex, bearing long narrow crests and three posterolateral setae on each side (Figure 3.1, 3.2). Superior volsella reniform, slightly elongated, with posteriorly directed rounded apex (Figure 3.3). Digitus not observed. Stem of median volsella bone-shaped, ca. $25 \mu \mathrm{m}$ long, with four leaf-shaped separated lamellae (Figure 3.4-6). Inferior volsella reaching one third the length of gonostylus, with distinctly swollen head-like apex bearing stout setae (setae omitted on Figure 3.2).

Remarks. Rheotanytarsus is a species-rich and greatly heteromorphic extant genus, but only two (the oldest) species are known from Eocene Baltic amber: Rh. alliciens Giłka and Zakrzewska, 2013, and $R h$. hoffeinsorum described here. These species differ distinctly from each other (cf. Giłka et al., 2013; see the key). Rh. hoffeinsorum combines some species-specific characters (the median vol- sella with bone-like stem bearing leaf-shaped separated lamellae) with those typical of extant species, and thus perceived as constant within the genus (the hypopygial anal tergite with the round field bearing median setae, the stout anal point with swollen apex, and the posteriorly directed superior volsella) (Figure 3). Essential information on the systematics, zoogeography and phylogeny of the genus have been published based on extant representatives distributed worldwide (Kyerematen et al., 2000; Kyerematen and Sæther, 2000; Andersen and Kyerematen, 2001; Kyerematen and Andersen, 2001; Sæther and Kyerematen, 2001).

Genus TANYTARSUS van der Wulp, 1874

Type species. Chironomus signatus van der Wulp, 1858 (designation: ICZN, 1961).

Tanytarsus crocota

Giłka, Zakrzewska and Krzemiński sp. nov.

Figures 4, 5

\section{zoobank.org/D7DF1DCB-7E39-440A-918F-0F7911E8F767}

Type material. Holotype. Adult male (entire thorax dorsally, head and legs partially hidden in a milky cloud, poorly observable) preserved in $11 \times 5.5 \times 3$ $\mathrm{mm}$ piece of amber (Eocene, $40-45 \mathrm{Ma}$, Gulf of Gdańsk; CCHH 1754-7; Figure 4.1).

Derivation of the name. From the Latin (golden yellow or saffron-coloured dress), with reference to the appearance of the inclusion; noun in apposition.

Diagnosis. Tibial spur of fore leg strong. Anal point slender, long, reaching far beyond apices of superior volsellae, spinulae not observed, crests long and narrow. Superior volsella finger-like, distinctly curved at mid length, apically rounded and medially directed. Digitus not observed. Median volsella sickle-shaped. Inferior volsella short, with prominent setal tubercles on apex.

Description. Adult male $(n=1)$.

Total length ca. $2.3 \mathrm{~mm}$; wing length ca. $1250 \mu \mathrm{m}$. Head (Figure 4.2). Eyes bare. Antenna with 13 well discernible flagellomeres, AR 0.85. Length of palpomeres 3-5 ( $\mu \mathrm{m})$ : 55, 110, 150.

Wing (Figure 4.3, 4.4). Ellipse-shaped, with anal lobe weak, broadest at 2/3 length, width: $365 \mu \mathrm{m}$, 

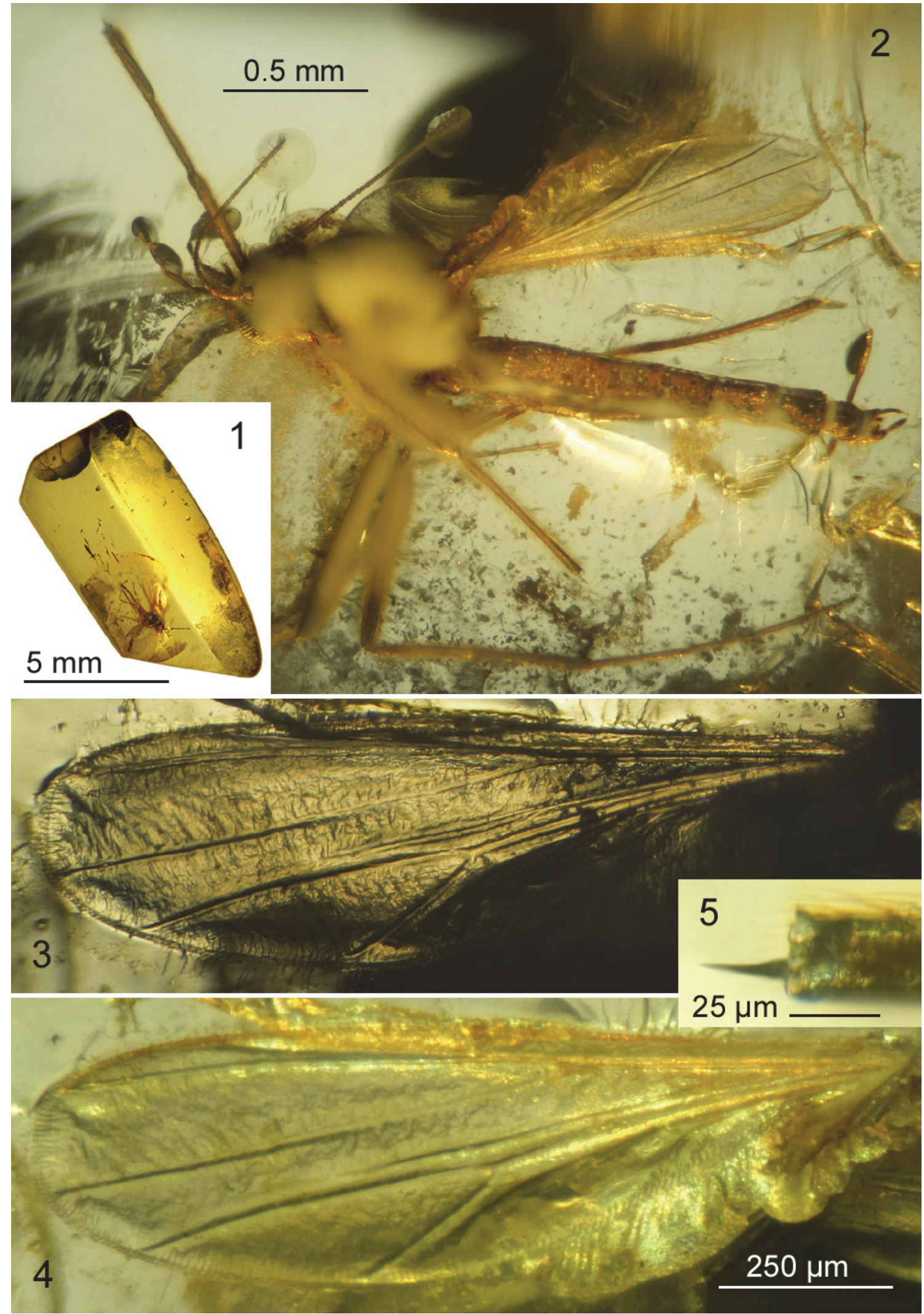

FIGURE 4. Tanytarsus crocota sp. nov., adult male, holotype. 1, inclusion in amber; 2, habitus; 3-4, wing photographed in transmitted (3) and reflected light (4); 5 , spur of fore leg tibia. 


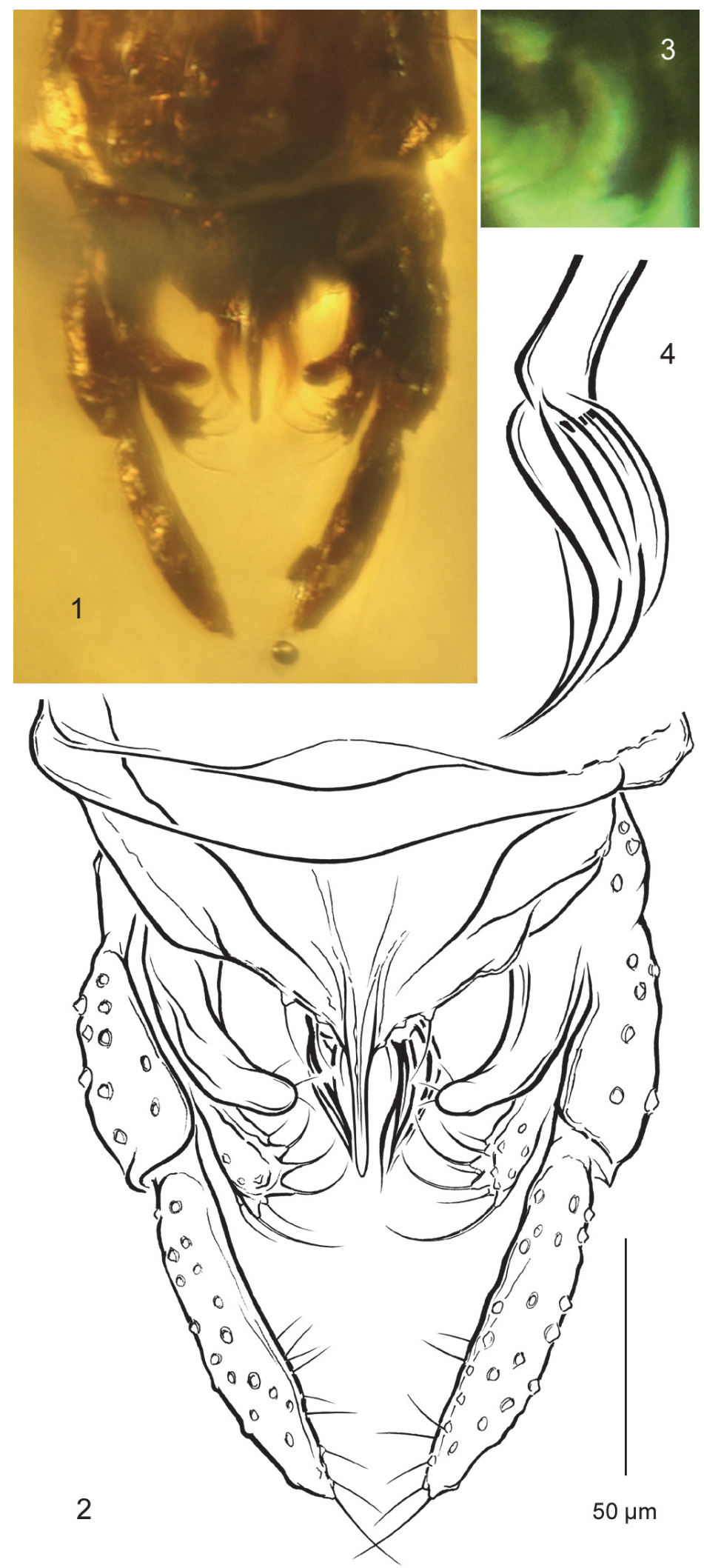

FIGURE 5. Tanytarsus crocota sp. nov., adult male, holotype. Hypopygium and its structures in dorsal $(\mathbf{1}, \mathbf{2})$ and ventral aspect $(3,4)$, photographed in reflected light (1), transmitted light (3) and drawn $(2,4)$; 3-4, median volsella (4 magnified ca. 3 times relative to 2 and 3 ). 
TABLE 5. Leg segment lengths $(\mu \mathrm{m})$ and leg ratios of male Tanytarsus crocota sp. nov. $p_{1}-p_{3}=p a i r$ of legs $1-3$, $\mathrm{fe}=$ femur, ti=tibia, $\mathrm{ta}_{1}-\mathrm{ta}_{5}=$ tarsomeres $1-5, \mathrm{LR}=$ leg ratio.

\begin{tabular}{ccccccccc}
\hline & $\mathbf{f e}$ & $\mathbf{t i}$ & $\mathbf{t a}_{1}$ & $\mathbf{t a}_{2}$ & $\mathbf{t a}_{3}$ & $\mathbf{t a}_{4}$ & $\mathbf{t a}_{5}$ & $\mathbf{L R}$ \\
\hline $\mathrm{p}_{1}$ & 660 & 595 & - & - & - & - & - & - \\
$\mathrm{p}_{2}$ & 690 & 630 & 370 & 210 & 160 & 90 & 65 & 0.59 \\
$\mathrm{p}_{3}$ & 645 & 690 & 410 & 245 & 200 & 105 & 75 & 0.59 \\
\hline
\end{tabular}

length/width ratio 3.42 . FCu placed distinctly distally of $\mathrm{RM} ; \mathrm{VR}_{\mathrm{Cu}}$ 1.24. Veins ending as follows (from base to tip): Sc (fading near RM), $\mathrm{An}, \mathrm{Cu}_{1}$, $R_{1}, R_{2+3}, M_{3+4}, R_{4+5}, M_{1+2}$. Wing chaetotaxy unobservable.

Legs. Tibia of fore leg with single, strong, ca. 25 $\mu \mathrm{m}$ long spur (Figure 4.5). Tibial combs of mid and hind legs separated, teeth up to $20 \mu \mathrm{m}$ long; each comb with spur, up to $30 \mu \mathrm{m}$ long (mid leg) and 40 $\mu \mathrm{m}$ long (hind leg). Sensilla chaetica on ta ${ }_{1}$ of $p_{2}$ not observed. Lengths of leg segments and leg ratios in Table 5.

Hypopygium (Figure 5). Gonostylus ca. $80 \mu \mathrm{m}$ long, slightly longer than gonocoxite, straight, apex pointed. Median setae on anal tergite not observed, 2-3 posterolateral setae on each side of anal point. Anal point long, reaching far beyond apices of superior volsellae, slender, narrowed at mid length, spinulae not observed, crests long and narrow. Superior volsella well developed, fingerlike, distinctly curved at mid length, apically rounded and medially directed, bearing 3 fine setae on apex. Digitus not observed. Median volsella sickle-shaped, with straight stem and several arcuate slender lamellae (Figure 5.3, 5.4). Inferior volsella short, reaching slightly over base of gonostylus, apical part with prominent setal tubercles bearing strong setae.

Remarks. The generic membership of the new species can be determined from a set of typical characters: the antenna consisting of 13 flagellomeres, the tibial combs of mid and hind legs separated, each bearing a spur, the gonostylus longer than the gonocoxite and the anal point with long crests. However, the exceptionally strong fore leg spur, the curved and finger-like superior volsella and the sickle-shaped median volsella are unique characters in the genus, in both fossil and extant species. Together they form a combination that makes the assignation of $T$. crocota to any species group open.
Tanytarsus glaesarius

Giłka and Zakrzewska, 2015

Figure 1

2015a Tanytarsus glaesarius Giłka and Zakrzewska in Zakrzewska and Giłka, p. 353, figures 5, 6 (male).

Material examined. Two adult males (syninclusions) in $8.5 \times 8 \times 3.5 \mathrm{~mm}$ piece of amber (Eocene, 40-45 Ma, Gulf of Gdańsk; CCHH 213-4, Figure 1): 1 male (tarsi of fore legs and left hind leg missing), 1 male (complete specimen).

Remarks. As Tanytarsus glaesarius was described recently on the basis of a single specimen, the original description can now be supplemented with the following characters: wing length $1140 \mu \mathrm{m}, \mathrm{AR}$ 0.98 (when flagellum measured as 10-segmented), AR 0.79 (as 11-segmented) (cf. Zakrzewska and Giłka, 2015a).

Tanytarsus protogregarius

Giłka and Zakrzewska, 2015

Figure 6.1, 6.2

2015a Tanytarsus protogregarius Giłka and Zakrzewska in Zakrzewska and Giłka, p. 356, figures 7, 8 (male).

Material examined. Five adult males in 4 pieces of amber (Eocene, 40-45 Ma, Gulf of Gdańsk, Figure 1): 1 male (CCHH 242-1, $11 \times 7 \times 2 \mathrm{~mm}) ; 1$ male (CCHH 242-11, $12 \times 7 \times 2.5 \mathrm{~mm}) ; 2$ males as syninclusions (CCHH 257-8, $19 \times 8.5 \times 5.5 \mathrm{~mm}) ; 1$ male $(\mathrm{CCHH} 1754-12$, triangular $7 \times 5 \times 4.5 \mathrm{~mm}$, Figure 6.1, 6.2).

Remarks. The imagines of fossil species display a distinct variability in the structures that are diagnostic. These are difficult to define, among others, due to the usually small number of specimens examined. Below we present the features of the recently described male Tanytarsus protogregarius, which are subject to intraspecific morphological variability and may be the reason for incorrect identification (see also Tanytarsus serafini). Figure 6.1 and 6.2 illustrate the atypical structure of the 


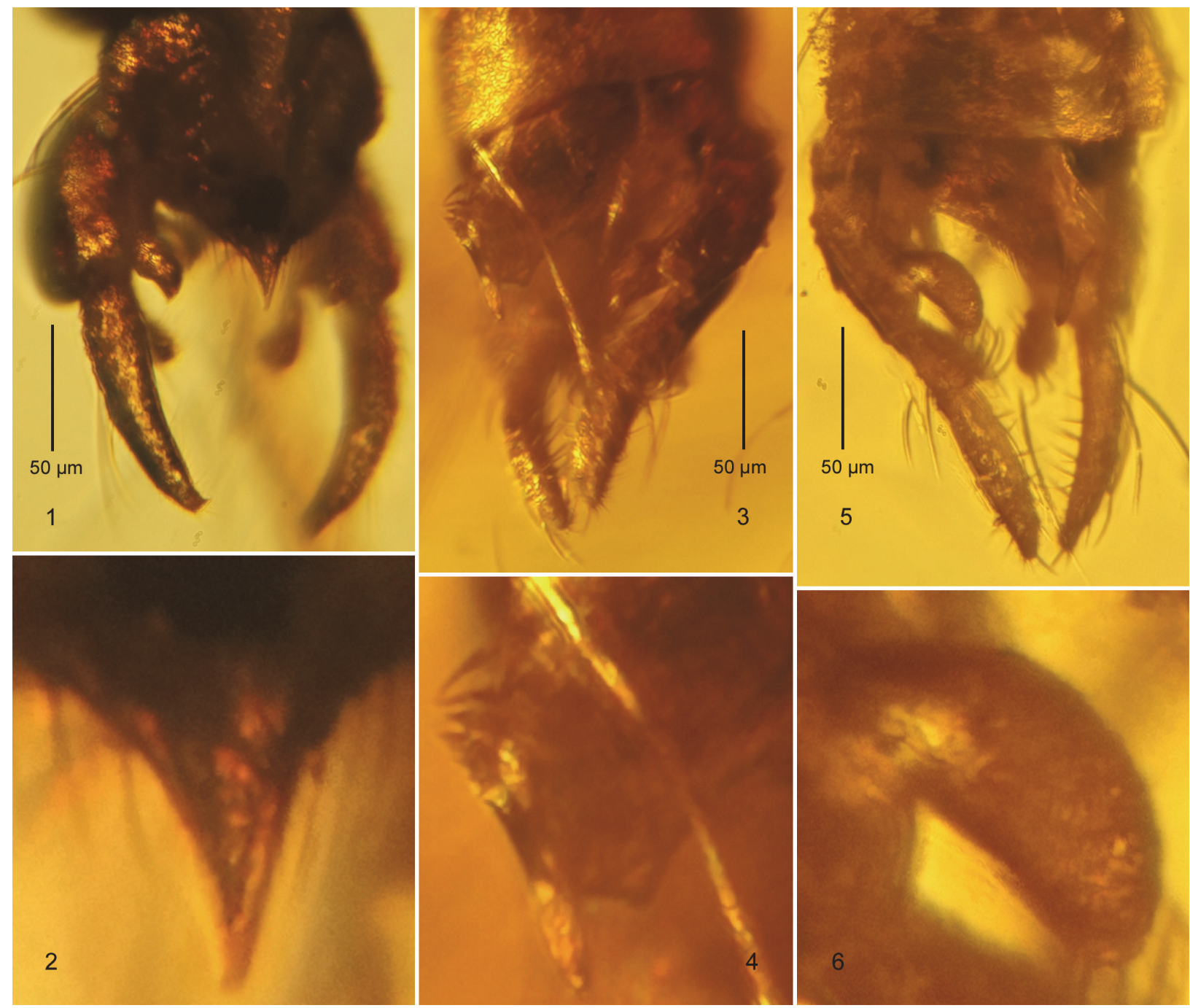

FIGURE 6. Variations of diagnostic structures in males of Tanytarsus protogregarius (1, 2) and T. serafini (3-6). Hypopygium in dorsolateral aspect $(\mathbf{1}, \mathbf{3}, \mathbf{5})$ and its structures magnified ca. 3-4 times (below): anal point $(2,4)$ and superior volsella (6).

hypopygial anal point, observed in one of the five specimens examined (cf. Zakrzewska and Giłka, 2015a).

\section{Tanytarsus serafini Giłka, 2010}

Figures 1, 6.3-6

2010 Tanytarsus serafini Giłka; Giłka, p. 715, plates 1-2 (male).

2013 Tanytarsus serafini Giłka; Giłka et al., p. 583, figure 8.

2014 Tanytarsus serafini Giłka; Zakrzewska and Giłka, p. 342 (in key).

2015a Tanytarsus serafini Giłka; Zakrzewska and Giłka, p. 359 (remarks).

Material examined. Eight adult males in 8 pieces of amber (Eocene, 40-45 Ma, Gulf of Gdańsk,
Figure 1): 1 male (CCHH 93-7, $14 \times 13.5 \times 5 \mathrm{~mm}$ ), syninclusions: Acari (2 ind. attached to abdomen); 1 male $(\mathrm{CCHH} 213-9,9 \times 8 \times 3.5 \mathrm{~mm}$, Figure 6.5, 6.6); 1 male $(\mathrm{CCHH} 242-2,11.5 \times 6.5 \times 3.5 \mathrm{~mm}$, Figure 6.3, 6.4); 1 male $(\mathrm{CCHH} 242-3,8.5 \times 7.5 \times 4$ $\mathrm{mm})$, syninclusions: Acari (2 ind.); 1 male $(\mathrm{CCHH}$ 257-9, triangular $20 \times 9.5 \times 5 \mathrm{~mm}) ; 1 \mathrm{male}(\mathrm{CCHH}$ 1754-2, $13 \times 13 \times 4 \mathrm{~mm}) ; 1$ male $(\mathrm{CCHH} 1754-3$, $10.5 \times 7.5 \times 5 \mathrm{~mm}) ; 1$ male $(\mathrm{CCHH} 1754-8,9.5 \times 8$ $\times 5 \mathrm{~mm})$.

Remarks. Tanytarsus serafini is the best known and one of the most frequently recorded species of Tanytarsini in Baltic amber. Figure 6.3-6 illustrates the structure of the anal tergite together with the median setae (these have become stuck together with resin, giving the impression that they are 

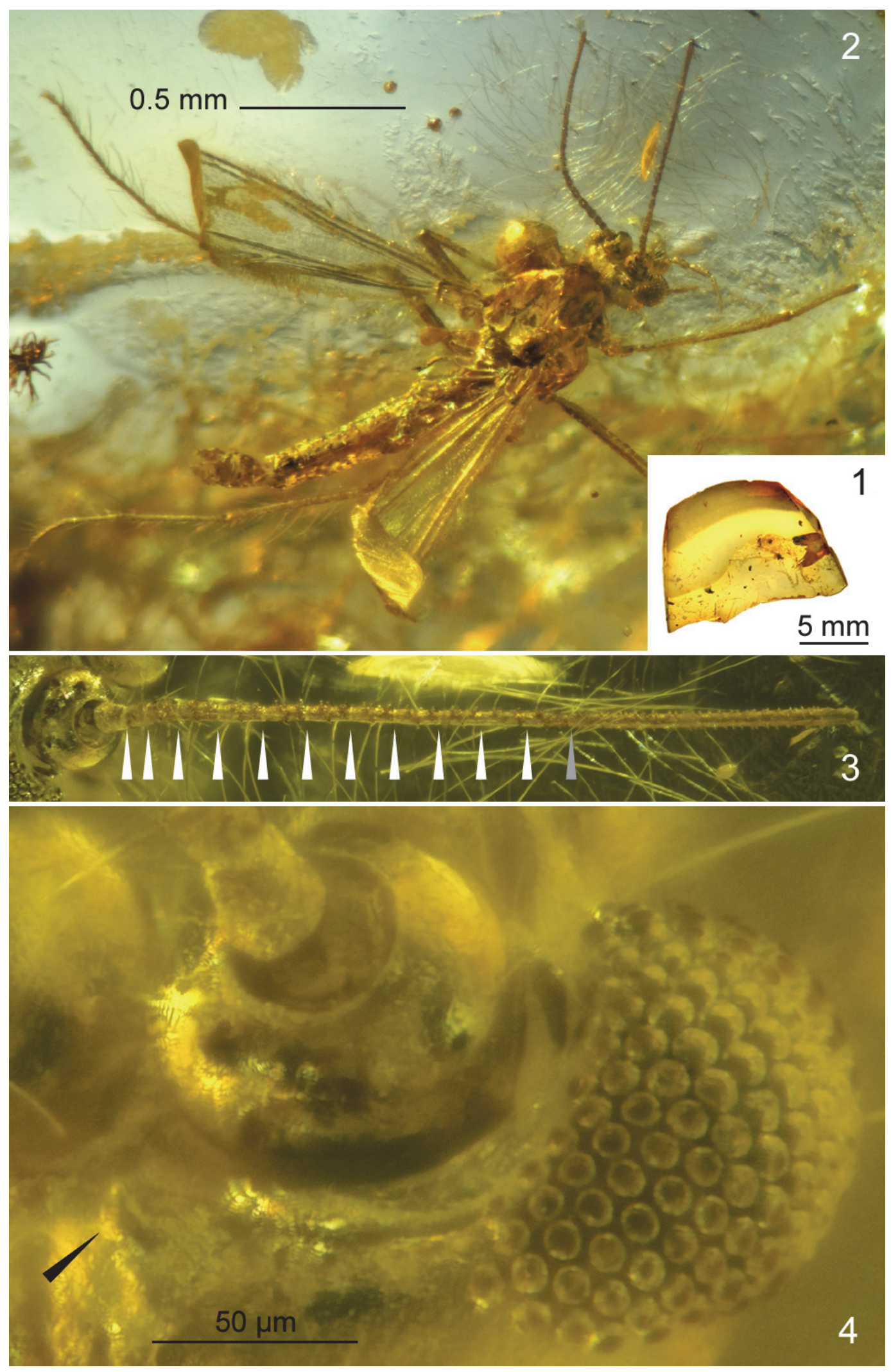

FIGURE 7. Stempellinella fibra sp. nov., adult male, holotype. 1, inclusion in amber; $\mathbf{2}$, habitus; $\mathbf{3}$, antenna (white arrows: borders between well discernible flagellomeres; grey arrow: incomplete fusion); 4, frontal tubercle (black arrow), antennal pedicel and eye. 

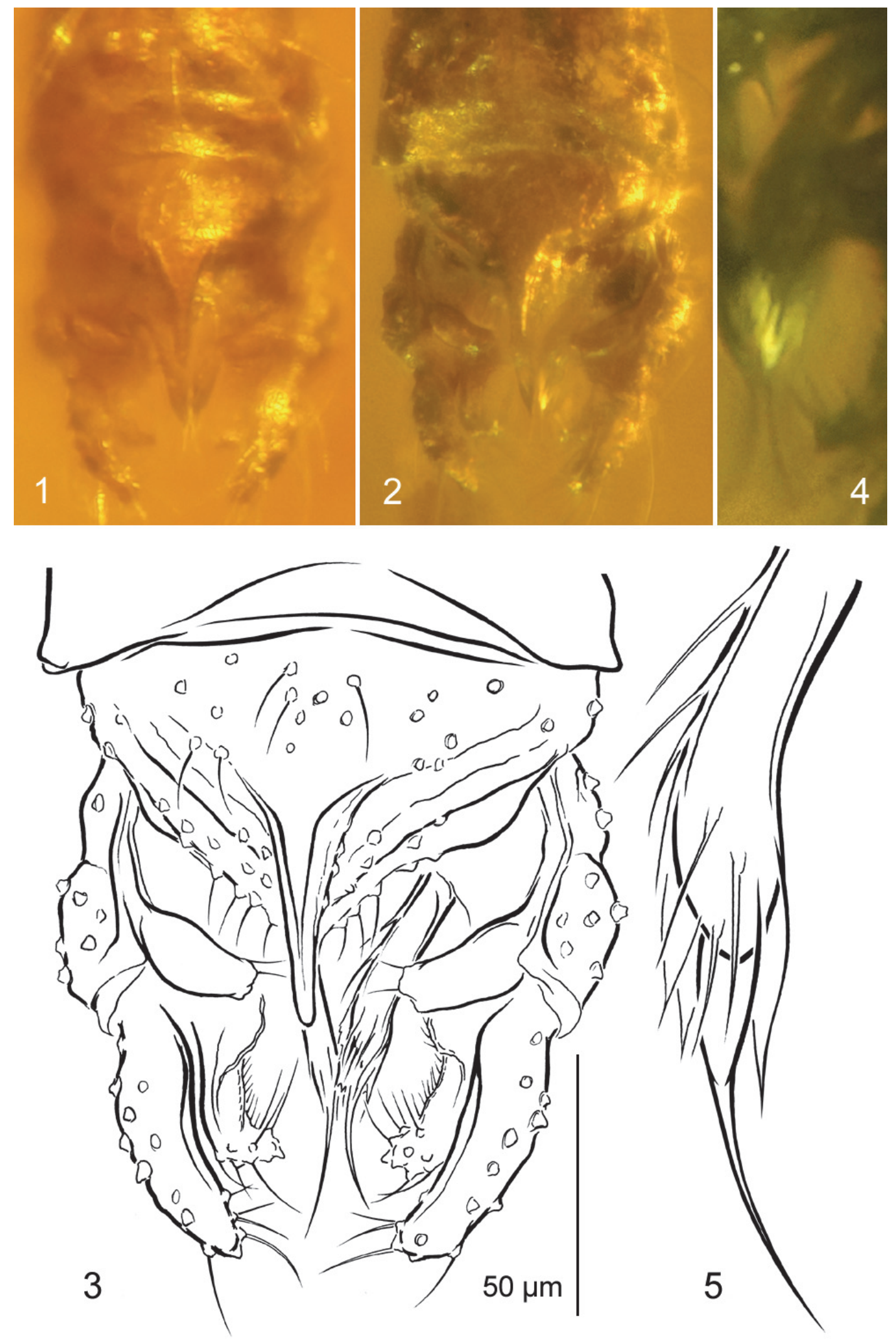

FIGURE 8. Stempellinella fibra sp. nov., adult male, holotype. Hypopygium and its structures in dorsal aspect, photographed in reflected light $(\mathbf{1}, \mathbf{2})$, in transmitted light $(4)$ and drawn $(3,5)$; 4-5, median volsella $(5$ magnified ca. 2 times relative to 4$)$. 
TABLE 6. Leg segment lengths $(\mu \mathrm{m})$ and leg ratios of male Stempellinella fibra sp. nov. $p_{1}-p_{3}=p a i r$ of legs $1-3$, $\mathrm{fe}=$ femur, ti=tibia, $\mathrm{ta}_{1}$-ta $\mathrm{ta}_{5}=$ tarsomeres $1-5$, LR=leg ratio.

\begin{tabular}{ccccccccc}
\hline & $\mathbf{f e}$ & $\mathbf{t i}$ & $\mathbf{t a}_{1}$ & $\mathbf{t a}_{2}$ & $\mathbf{t a}_{3}$ & $\mathbf{t a}_{4}$ & $\mathbf{t a}_{5}$ & $\mathbf{L R}$ \\
\hline $\mathrm{p}_{1}$ & 470 & 225 & - & - & - & - & - & - \\
$\mathrm{p}_{2}$ & 490 & - & 260 & 120 & 95 & 70 & 45 & - \\
$\mathrm{p}_{3}$ & - & 425 & 325 & 180 & 150 & 105 & 55 & 0.76 \\
\hline
\end{tabular}

spinulae) and an atypical structure of the superior volsella (cf. Giłka, 2010).

Subtribe ZAVRELIINA Sæther, 1977 Genus STEMPELLINELLA Brundin, 1947

Type species. Tanytarsus saltuum Goetghebuer, 1921 (designation in the original description of the genus).

\section{Stempellinella fibra \\ Giłka, Zakrzewska and Krzemiński sp. nov. Figures 7, 8}

zoobank.org/4A5DDD2E-6929-45B8-9652-399D973F1410

Type material. Holotype. Adult male (left fore and left mid leg missing or unobservable, tarsus of right fore leg missing; thorax damaged in part, apices of wings bent and faintly observable) preserved in $18.5 \times 15 \times 8.5 \mathrm{~mm}$ piece of amber (Eocene, 40$45 \mathrm{Ma}$, Gulf of Gdańsk; CCHH 257-5; Figure 7.1).

Derivation of the name. From the Latin (fibre, filament), with reference to the strongly elongated filiform hypopygial lamella; noun in apposition.

Diagnosis. Antennal flagellum consisting of 13 flagellomeres (12-13 fused in part). Anal point stout, with strong crests. Superior volsella extensive, bean-shaped, apex broad with distinct protuberances. Stem of median volsella long, clubshaped, bearing slender foliate lamellae, single lamella with strongly elongated filiform tip. Inferior volsella with broad dorsomedian extension at base and apical part distinctly bent medially, covered with long microtrichia.

Description. Adult male $(n=1)$.

Total length ca. $1.55 \mathrm{~mm}$.

Head (Figure 7.3, 7.4). Eyes bare, small, ovoid, broadly separated by frons. Frontal tubercles conical, ca. $15 \mu \mathrm{m}$ long (Figure 7.4). Antenna with 13 flagellomeres, 12 of which are readily discernible, flagellomeres 12-13 fused in part, AR 0.68 (when flagellum measured as 12-segmented), AR 0.52 (as 13-segmented); plume fully developed (Figure 7.3). Length of palpomeres 2-5 (in $\mu \mathrm{m}$ ): ca. 28,58 , 68,117 . Clypeus with at least 8 setae.

Wing. Slender, with anal lobe weak, broadest at $2 / 3$ length. Sc ending distal of RM. FCu placed distinctly distally of $R M$; $V_{R_{C u}} 1.55$. Chaetotaxy and other characters of wing unobservable (Figure 7.2).
Legs. Tibial apices with their armature faintly visible. Sensilla chaetica on $\mathrm{ta}_{1}$ of $\mathrm{p}_{2}$ not observed. Lengths of leg segments and leg ratios in Table 6. Hypopygium (Figure 8). Gonostylus short, ca. 60 $\mu \mathrm{m}$, as long as gonocoxite, slightly arcuate, broadest in proximal part, blunt apex armed with strong apical setae. Anal tergite subtriangular, with several median setae and four-five posterolateral setae on each side of anal point. Anal point stout, reaching slightly beyond apices of superior volsellae, tapering to blunt apex, with strong crests. Superior volsella extensive, bean-shaped, apex broad with distinct protuberances bearing two fine setae. Digitus not observed. Stem of median volsella long (ca. $30 \mu \mathrm{m}$ ), club-shaped, bearing several setiform and four slender foliate lamellae, including single foliate lamella with extraordinarily elongated filiform tip (Figure 8.3-5). Inferior volsella reaching $3 / 4$ length of gonostylus, with broad dorsomedian extension at base, posteriorly directed, with apical part distinctly bent medially, covered with long microtrichia (distinctly visible on median margin), bearing several strong setae.

Remarks. Among all the described Stempellinella species, both fossil and extant, S. fibra is distinguished by a combination of extraordinarily structured hypopygial volsellae. The best diagnostic character is the robust median volsella, consisting of a club-shaped stem armed with several slender foliate lamellae, one of which is strongly elongated into a filiform tip (Figure 8.5). A slightly similar but smaller median volsella is observed in S. ciliaris (Goetghebuer, 1944), the comparatively long but sinuous stem is known from $S$. coronata Inoue et al., 2004, whereas similarly long but setiform lamellae - from S. lamellata Ekrem, 2007 (Ekrem, 2007 , figures $9,11,19)$. The inferior volsella covered with long microtrichia, with the broad dorsomedian extension at base found in S. fibra, is also a diagnostic structure unknown from either extant or fossil Stempellinella. The tendency towards the formation of a fully developed antenna (13 flagellomeres) observed in other fossil Stempellinella (cf. Zakrzewska and Giłka, 2014, 2015a) is now confirmed in S. fibra (Figure 7.3).

A list of Stempellinella species recently presented 
(Zakrzewska and Giłka, 2015a) is now extended with S. fibra and complemented with S. depilisa Guo and Wang, 2007 from China, thus comprises 20 extant species worldwide and four extinct species described from ambers of the Baltic region.

\section{CONCLUDING REMARKS}

We still know little about the origins of the Tanytarsini and the diversity of this tribe in the past. What studies of Baltic amber and of the extant Tanytarsini of Europe have so far revealed about the diversity of these species is that there are considerable disproportions: 8 genera and 20 species vs. 16 genera and 190 extant species recorded in Europe (Giłka, 2011b; Giłka and Jażdżewska, 2012; Sæther and Spies, 2013). As it has up till now been evidenced, the majority of genera persisting since the Eocene are distributed worldwide (Tanytarsus, Rheotanytarsus Stempellina, and Stempellinella), except for Caladomyia - known mainly from the Neotropics (Zakrzewska and Giłka, 2013). Even though such a comparison relates to geographical areas that have been undergoing transformations for the past 40 million years, it still seems to be the only reasonable approach yielding an approximate rate of speciation. Remarks on species diversity and evolutionary trends in Eocene Tanytarsini have

TABLE 7. Diversity of Tanytarsini taxa with numbers of specimens examined from different collections of Eocene Baltic amber examined (Giłka, 2010, 2011a; Giłka et al., 2013; Zakrzewska and Giłka, 2013, 2014, 2015a, 2015b). + for taxon present in the collection; - for taxon absent from the collection; $\mathrm{CCHH}=$ the collection of Christel and Hans Werner Hoffeins, Germany; MAI=collection of the Museum of Amber Inclusions, University of Gdańsk, Poland; SIZ=collection of the I.I. Schmalhausen Institute of Zoology, National Academy of Sciences of Ukraine, Kiev, Ukraine.

\begin{tabular}{|c|c|c|c|c|}
\hline Genus & Species & $\begin{array}{c}\text { CCHH } \\
\text { Gulf of Gdańsk }\end{array}$ & $\begin{array}{c}\text { MAl } \\
\text { Gulf of Gdańsk }\end{array}$ & $\begin{array}{c}\text { SIZ } \\
\text { Rovno region }\end{array}$ \\
\hline \multirow[t]{4}{*}{ Archistempellina } & & + & - & + \\
\hline & bifurca & - & - & 1 \\
\hline & falcifera & 1 & - & 1 \\
\hline & perkovskyi & 1 & - & 1 \\
\hline \multirow[t]{2}{*}{ Caladomyia } & & + & - & - \\
\hline & szadziewskii & 1 & - & - \\
\hline \multirow[t]{2}{*}{ Corneliola } & & + & + & + \\
\hline & avia & 5 & 16 & 4 \\
\hline \multirow[t]{3}{*}{ Eonandeva } & & + & - & - \\
\hline & helva & 1 & - & - \\
\hline & latistyla & 1 & - & - \\
\hline \multirow[t]{3}{*}{ Rheotanytarsus } & & + & - & + \\
\hline & alliciens & - & - & 1 \\
\hline & hoffeinsorum & 1 & - & - \\
\hline \multirow[t]{4}{*}{ Stempellinella } & & + & + & + \\
\hline & electra & - & 1 & - \\
\hline & fibra & 1 & - & - \\
\hline & ivanovae & - & 1 & 1 \\
\hline \multirow[t]{7}{*}{ Tanytarsus } & & + & + & + \\
\hline & congregabilis & - & - & 3 \\
\hline & crocota & 1 & - & - \\
\hline & fereci & - & 1 & - \\
\hline & glaesarius & 2 & 1 & - \\
\hline & protogregarius & 5 & 3 & - \\
\hline & serafini & 8 & 4 & 1 \\
\hline $\begin{array}{l}\text { Total number } \\
\text { of genera/species }\end{array}$ & & $7 / 12$ & $3 / 7$ & $5 / 8$ \\
\hline
\end{tabular}


recently been discussed by Zakrzewska and Giłka (2014).

With the exception of the two species described by Seredszus and Wichard (2007), the descriptions of all the other Eocene Tanytarsini are the result of our studies, based on three rich collections of Baltic amber inclusions from this period: the Hoffeins collection $(\mathrm{CCHH})$, the Museum of Amber Inclusions, University of Gdańsk (MAI), and the I.I. Schmalhausen Institute of Zoology, National Academy of Sciences of Ukraine, Kiev (SIZ) (Table 7). This has allowed us to make a preliminary assessment of the diversity, and also the frequency and numbers of Tanytarsini recorded in ambers from the Baltic region. The species found in all three collections, in amber obtained from different deposits, are Corneliola avia (a total of 25 specimens in 12 pieces of amber) and Tanytarsus serafini (13 specimens in 12 pieces of amber); these are regarded as having been numerous and/or common (Table 7). Species turning up frequently but as single or at most a pair of specimens (syninclusions) were Tanytarsus glaesarius and T. protogregarius (Giłka, 2010; Giłka et al., 2013; Zakrzewska and Giłka, 2014, 2015a). Comparison of these three amber collections shows that the Hoffeins collection exhibits the greatest diversity. There we found a total of 12 species from 7 genera, including one new genus Eonandeva and 6 species described as new (3 in the present work) (for detailed data see Table 7).

\section{Updated key to the identification of genera and species of the tribe Tanytarsini recorded in Eocene Baltic amber}

\begin{tabular}{|c|c|c|}
\hline 1. Hypopygium with gonostyli straight, posteriorly directed (Figures 2-8) & Chironominae & 2 \\
\hline -. Hypopygium with gonostyli bent, medially directed & $\begin{array}{l}\text { other Chironomidae } \\
\text { (not keyed) }\end{array}$ & \\
\hline $\begin{array}{l}\text { 2. Wing vein RM parallel or slightly oblique relative to } \mathrm{R} \text { and } \mathrm{M} \text {, anal lobe weak or not } \\
\text { developed, squama bare (Figure } 4.3,4.4 \text { ) }\end{array}$ & Tanytarsini & 3 \\
\hline $\begin{array}{l}\text {-. Wing vein } \mathrm{RM} \text { transverse relative to } \mathrm{R} \text { and } \mathrm{M} \text {, anal lobe well developed, squama with } \\
\text { fringe of setae }\end{array}$ & $\begin{array}{l}\text { other Chironominae } \\
\text { (not keyed) }\end{array}$ & \\
\hline $\begin{array}{l}\text { 3. Superior volsella stout, strongly elongated; gonostylus with subapical lobe on median } \\
\text { margin (Zakrzewska and Giłka, 2015b, figures 2, 4); median volsella absent }\end{array}$ & Eonandeva & 4 \\
\hline -. Superior volsella and gonostylus never as above, median volsella present & & 5 \\
\hline $\begin{array}{l}\text { 4. Gonostylus slender, subapical lobe small; median setae absent; superior volsella cylindrical; } \\
\text { inferior volsella with slightly enlarged apical part (Zakrzewska and Giłka, 2015b, figure 2) }\end{array}$ & E. helva & \\
\hline $\begin{array}{l}\text {-.Gonostylus broad near apex, subapical lobe large; median setae present; superior } \\
\text { volsella swollen in apical part; inferior volsella with distinctly enlarged head-like apical } \\
\text { part (Zakrzewska and Giłka, 2015b, figure 4) }\end{array}$ & E. latistyla & \\
\hline $\begin{array}{l}\text { 5. Dorsomedian extension of eye well developed (Giłka et al., 2013, figures 2, 3, 6, 8; } \\
\text { Zakrzewska and Giłka, 2015a, figures 5, 7). Wing vein } \mathrm{R}_{4+5} \text { ending distal of } \mathrm{M}_{3+4} \text { to wing } \\
\text { apex (Figure 4.3, 4.4; Giłka, 2010, plate 2; Giłka, 2011a, figure 2; Giłka et al., 2013, figures } \\
\text { 1, 2, 4, 6, 7; Zakrzewska and Giłka, 2013, figure 1; Zakrzewska and Giłka, 2014, figure 1; } \\
\text { Zakrzewska and Giłka, 2015a, figures 5, 7) }\end{array}$ & & 6 \\
\hline $\begin{array}{l}\text { - Dorsomedian extension of eye not developed (Figure } 7.4 \text {; Zakrzewska and Giłka, } \\
\text { 2015a, figure 3). Wing vein } \mathrm{R}_{4+5} \text { ending opposite or proximal of } \mathrm{M}_{3+4} \text { to wing apex } \\
\text { (Seredszus and Wichard, } 2007 \text {, figures } 18,19 \text {, plates } 5 \mathrm{c} \text {, d; Zakrzewska and Giłka, } \\
2014 \text {, figure 3; Zakrzewska and Giłka, 2015a, figure } 3 \text { ) }\end{array}$ & & 18 \\
\hline $\begin{array}{l}\text { 6. Superior volsella small, boomerang-shaped or cylindrical; median volsella with two slender } \\
\text { falciform lamellae (Giłka et al., 2013, figures 1, 2; Zakrzewska and Giłka, 2014, figure 2) }\end{array}$ & Archistempellina & 7 \\
\hline
\end{tabular}




\begin{tabular}{|c|c|c|}
\hline $\begin{array}{l}\text { - Superior volsella well developed, elongated and/or broadened, roundish, bean- } \\
\text { shaped or reniform; median volsella never with two slender falciform lamellae (Figures } \\
\text { 3, 5; Giłka, 2010, plate 2; Giłka, 2011a, figure 2; Giłka et al., 2013, figures 4, 6, 7; } \\
\text { Zakrzewska and Giłka, 2013, figure 2; Zakrzewska and Giłka, 2015a, figures 6, 8) }\end{array}$ & & 9 \\
\hline $\begin{array}{l}\text { 7. Anal tergite with semicircular posterolateral lobes covered with dense setae; superior } \\
\text { volsella boomerang-shaped, with triangular tip; stem of median volsella posteromedially } \\
\text { directed, tip narrow (Zakrzewska and Giłka, 2014, figure 2) }\end{array}$ & A. perkovskyi & \\
\hline $\begin{array}{l}\text { - Anal tergite without semicircular posterolateral lobes covered with dense setae; } \\
\text { superior volsella cylindrical, swollen in distal part; stem of median volsella medially } \\
\text { directed, tip swollen (Giłka et al., 2013, figures 1,2) }\end{array}$ & & 8 \\
\hline $\begin{array}{l}\text { 8. Anal point acute, reaching over superior and median volsellae; stem of median volsella } \\
\text { longer than its falciform lamellae (Giłka et al., 2013, figure 1) }\end{array}$ & A. bifurca & \\
\hline $\begin{array}{l}\text { Anal point with swollen roundish tip, reaching bases of median and inferior volsellae; } \\
\text { stem of median volsella and its falciform lamellae of the same length (Giłka et al., } \\
\text { 2013, figure 2) }\end{array}$ & A. falcifera & \\
\hline 9. Eyes hairy; gonostylus with strong spine-like apical bristle (Giłka et al., 2013, figure 4) & $\begin{array}{l}\text { Corneliola } \\
\text { C. avia }\end{array}$ & \\
\hline $\begin{array}{l}\text {-. Eyes bare; gonostylus with simple apical seta at most (Figures 3, 5; Giłka, 2010, plate } \\
\text { 2; Giłka, 2011a, figure 2; Giłka et al., 2013, figures 6, 7; Zakrzewska and Giłka, 2013, } \\
\text { figure 2; Zakrzewska and Giłka, 2015a, figures 6, 8) }\end{array}$ & & 10 \\
\hline $\begin{array}{l}\text { 10. Superior volsella round with slightly projecting posterior part or reniform and posteriorly } \\
\text { directed (Figure } 3 \text {, Giłka et al., 2013, figure } 6 \text { ) }\end{array}$ & Rheotanytarsus & 11 \\
\hline $\begin{array}{l}\text { - Superior volsella elongated, posteromedially or medially directed; if posteriorly } \\
\text { directed, then with nipple-like extension (Figure 5; Giłka, 2010, plate 2; Giłka et al., } \\
\text { 2013, figure 7; Zakrzewska and Giłka, 2013, figure 2; Zakrzewska and Giłka, 2015a, } \\
\text { figures 6, 8) }\end{array}$ & & 12 \\
\hline $\begin{array}{l}\text { 11. Anal point tapering to slender tip; superior volsella round; digitus present; stem of median } \\
\text { volsella stout and short, simple, with pectinate or leaf-shaped lamellae fused at bases (Giłka } \\
\text { et al., 2013, figure 6) }\end{array}$ & Rh. alliciens & \\
\hline $\begin{array}{l}\text {-. Anal point with swollen tip; superior volsella reniform; digitus not observed; stem of } \\
\text { median volsella bone-shaped, with leaf-shaped separated lamellae (Figure 3) }\end{array}$ & Rh. hoffeinsorum & \\
\hline $\begin{array}{l}\text { 12. Anal point with horizontally expanded lateral enlargements and small distal section } \\
\text { between; posteriorly directed bar present (Zakrzewska and Giłka, 2013, figure 2) }\end{array}$ & $\begin{array}{l}\text { Caladomyia } \\
\text { C. szadziewskii }\end{array}$ & \\
\hline $\begin{array}{l}\text { Anal point without lateral enlargements, distal section or bar (Figure 5; Giłka, 2010, } \\
\text { plate 2; Giłka, 2011a, figure 2; Giłka et al., 2013, figure 7; Zakrzewska and Giłka, } \\
\text { 2015a, figures 6, 8) }\end{array}$ & Tanytarsus & 13 \\
\hline $\begin{array}{l}\text { 13. Wing veins } R \text { and } M \text { very short, nearly half as long as } \mathrm{Cu}, V_{\mathrm{Cu}} 1.70-1.82 \text {; stem of median } \\
\text { volsella with setiform and slender subuliform lamellae (Giłka, 2010, plate } 2 \text { ) }\end{array}$ & T. serafini & \\
\hline $\begin{array}{l}\text {-Wing veins } \mathrm{R} \text { and } \mathrm{M} \text { long, } \mathrm{VR}_{\mathrm{Cu}} \text { 1.16-1.52. Stem of median volsella with arcuate, } \\
\text { spindle-shaped, leaf-shaped (foliate) lamellae (Figure 5; Giłka, 2011a, figure 2; Giłka } \\
\text { et al., 2013, figure 7; Zakrzewska and Giłka, 2015a, figures } 6,8 \text { ) }\end{array}$ & & 14 \\
\hline $\begin{array}{l}\text { 14. Digitus well developed, extending beyond superior volsella (Zakrzewska and Giłka, 2015a, } \\
\text { figure } 6 \text { ) }\end{array}$ & T. glaesarius & \\
\hline -. Digitus not observed & & 15 \\
\hline $\begin{array}{l}\text { 15. Ultimate palpomere with strong stiff apical seta; anal tergite with longitudinal crest-like } \\
\text { hump bearing median setae (Giłka, 2011a, figures 1, 2) }\end{array}$ & T. fereci & \\
\hline
\end{tabular}




\begin{tabular}{|c|c|c|}
\hline $\begin{array}{l}\text {-. Ultimate palpomere without stiff apical seta; anal tergite without longitudinal hump, } \\
\text { median setae absent (Figure 5; Giłka et al., 2013, figure 7; Zakrzewska and Giłka, } \\
\text { 2015a, figure 8) }\end{array}$ & & 16 \\
\hline $\begin{array}{l}\text { 16. Gonostylus straight, with long seta on apex; superior volsella finger-like, distinctly curved } \\
\text { at mid length and medially directed; median volsella sickle-shaped with slender arcuate } \\
\text { lamellae (Figure 5) }\end{array}$ & T. crocota & \\
\hline $\begin{array}{l}\text { - Gonostylus curved at mid length or boomerang-like, with subapical tooth-like process; } \\
\text { superior volsella bean-shaped or with nipple-like apical extension, straight, } \\
\text { posteromedially or posteriorly directed; median volsella never sickle-shaped, bearing } \\
\text { leaf-shaped (foliate) lamellae (Figure 6.1; Giłka et al., 2013, figure 7; Zakrzewska and } \\
\text { Giłka, 2015a, figure 8) }\end{array}$ & & 17 \\
\hline 17. Stem of median volsella bulb-shaped (Giłka et al., 2013, figure 7) & T. congregabilis & \\
\hline -. Stem of median volsella straight (Zakrzewska and Giłka, 2015a, figure 8) & T. protogregarius & \\
\hline 18. Gonostylus distinctly longer than gonocoxite (Seredszus and Wichard, 2007, figure 18) & $\begin{array}{l}\text { Stempellina } \\
\text { S. exigua }\end{array}$ & \\
\hline $\begin{array}{l}\text { - Gonostylus shorter than or as long as gonocoxite (Figure 8; Seredszus and Wichard, } \\
\text { 2007, figure 19; Zakrzewska and Giłka, 2014, figure 4; Zakrzewska and Giłka, 2015a, } \\
\text { figure 4) }\end{array}$ & Stempellinella & 19 \\
\hline $\begin{array}{l}\text { 19. Gonostylus with apical nipple-like process; anal point with spinulae; superior volsella } \\
\text { posteriorly directed; inferior volsella with beak-like protrusion (Zakrzewska and Giłka, 2014, } \\
\text { figure 4) }\end{array}$ & S. ivanovae & \\
\hline $\begin{array}{l}\text { - Gonostylus without apical nipple-like process; anal point without spinulae; superior } \\
\text { volsella medially directed; inferior volsella without beak-like protrusion (Figure 8; } \\
\text { Seredszus and Wichard, 2007, figure 19; Zakrzewska and Giłka, 2015a, figure 4) }\end{array}$ & & 20 \\
\hline $\begin{array}{l}\text { 20. Antennal flagellum consisting of } 10 \text { flagellomeres; median volsella shorter than superior } \\
\text { volsella (Seredszus and Wichard, 2007, figure 19) }\end{array}$ & S. bicorna & \\
\hline $\begin{array}{l}\text {-. Antennal flagellum consisting of } 13 \text { flagellomeres, flagellomeres } 11-13 \text { or } 12-13 \text { fused } \\
\text { in part (Figure 7.3; Zakrzewska and Giłka, 2015a, figure 3); median volsella longer } \\
\text { than superior volsella (Figure 8.3; Zakrzewska and Giłka, 2015a, figure 4) }\end{array}$ & & 21 \\
\hline $\begin{array}{l}\text { 21. Median volsella (stem with its lamellae) distinctly shorter than gonostylus, bearing wide } \\
\text { pectinate and foliate lamellae (Zakrzewska and Giłka, 2015a, figure 4) }\end{array}$ & S. electra & \\
\hline $\begin{array}{l}\text {-. Median volsella (stem with its lamellae) and gonostylus of similar length, bearing } \\
\text { slender foliate lamellae, single lamella with strongly elongated filiform tip (Figure } 8 \text { ) }\end{array}$ & S. fibra & \\
\hline
\end{tabular}

\section{ACKNOWLEDGEMENTS}

We are greatly indebted to C. and H.W. Hoffeins (Hamburg) for placing their unique material at our disposal. The first author's project was financially supported by the University of Gdańsk ('Young Researcher', grant No. 538-L114-B60415).

\section{REFERENCES}

Andersen, T. and Kyerematen, R.A.K. 2001. South American Rheotanytarsus Thienemann et Bause, with the description of one new species (Diptera: Chironomidae). Norwegian Journal of Entomology, 48:269-274.
Bause, E. 1913. Die Metamorphose der Gattung Tanytarsus und einiger verwandter Tendipedidenart. Ein Beitrag zur Systematic der Tendipediden. Archiv für Hydrobiologie, supplement 2:1-126.

Brundin, L. 1947. Zur Kenntnis der Swedischen Chironomiden. Arkiv för Zoologi, 39:1-95.

Cranston, P.S., Hardy, N.B., and Morse, G.E. 2012. A dated molecular phylogeny for the Chironomidae (Diptera). Systematic Entomology, 37:172-188. doi:10.1111/j.1365-3113.2011.00603.x

Ekrem, T. 2007. A taxonomic revision of the genus Stempellinella (Diptera: Chironomidae). Journal of Natural History, 41:1367-1465. doi:10.1080/00222930701437360

Ekrem, T., Sublette, M.F., and Sublette, J.E. 2003. North American Tanytarsus I. Descriptions and keys to species in the eminulus, gregarius, lugens and mendax 
species groups (Diptera: Chironomidae). Annals of the Entomological Society of America, 96:265-328.

doi:10.1603/0013-

8746(2003)096[0265:NATIDA]2.0.CO;2

Giłka, W. 2010. A new species group in the genus Tanytarsus van der Wulp (Diptera: Chironomidae) based on a fossil record from Baltic amber. Acta Geologica Sinica (English Edition), 84:714-719. doi:10.1111/j.1755-6724.2010.00249.x

Giłka, W. 2011a. A new fossil Tanytarsus from Eocene Baltic amber, with notes on systematics of the genus (Diptera: Chironomidae). Zootaxa, 3069:63-68.

Giłka, W. 2011b. Analiza różnorodności faunistycznej ochotkowatych z plemienia Tanytarsini w Europie (Diptera: Chironomidae). [Analysis of faunistic diversity in chironomids of the tribe Tanytarsini in Europe (Diptera: Chironomidae)]. Dipteron, Bulletin of the Dipterological Section of the Polish Entomological Society, 27:11-31. [in Polish]

Giłka, W. and Jażdżewska, N. 2012. Description of a new species in the Micropsectra atrofasciata group, with notes on rare Tanytarsini in Poland (Diptera: Chironomidae). Polish Journal of Entomology, 81:157-164 doi:10.2478/v10200-012-0004-0

Giłka, W., Zakrzewska, M., Dominiak, P., and Urbanek, A. 2013. Non-biting midges of the tribe Tanytarsini in Eocene amber from the Rovno region (Ukraine): a pioneer systematic study with notes on the phylogeny (Diptera: Chironomidae). Zootaxa, 3736:569586. doi:10.11646/zootaxa.3736.5.8

Goetghebuer, M. 1921. Chironomides de Belgique et spécialement de la zone des Flandres. Mémoires du Musée Royal d'Histoire Naturelle de Belgique, 8:1211.

Goetghebuer, M. 1944. Ceratopogonidae et Chironomidae nouveaux ou peu connus d'Europe (douzième note). Biologisch Jaarboek, 11:35-44.

Goetghebuer, M. and Lenz, F. 1954. Tendipedidae-Tendipedinae (Chironomidae -Chironominae). In Fliegen palaearktische Region (key series), 13c:129-168.

Guo, Y. and Wang, X. 2007. Stempellinella depilisa sp. nov. from China (Diptera, Chironomidae, Tanytarsini). Acta Zootaxonomica Sinica, 32(2):321-323.

ICZN 1961. International Commission on Zoological Nomenclature. Opinion 616. Tanytarsus van der Wulp, 1874 (Insecta, Diptera); designation of a typespecies under the plenary powers. Bulletin of Zoological Nomenclature, 18:361-362.

Inoue, E., Kawai, K. and Imabayashi, H. 2004. A new species of the genus Stempellinella (Diptera: Chironomidae) from Hiroshima, Japan. Limnology, 5:141-147. doi:10.1007/s10201-004-0131-8

Kieffer, J.J. 1909. Diagnoses de noveaux Chironomids d'Allemagne. Bulletin de la Société d'Histoire Naturelle de Metz, 26:37-56.
Krzemiński, W. and Jarzembowski, E. 1999. Aenne triassica sp. n., the oldest representatives of the family Chironomidae (Insecta: Diptera). Polskie Pismo Entomologiczne, 68:445-449.

Kyerematen, R.A.K. and Andersen, T. 2001. Rheotanytarsus Thienemann et Bause (Diptera: Chironomidae) from Central America and Mexico. Studies on Neotropical Fauna and Environment, 36:1-39. doi:10.1076/snfe.37.1.23.2113

Kyerematen, R.A.K. and Sæther, O.A. 2000. A review of Afrotropical Rheotanytarsus distinctissimus Thienemann et Bause, 1913 (Diptera: Chironomidae). Tijdschrift voor Entomologie, 143:27-69.

Kyerematen, R.A.K., Andersen, T., and Sæther, O.A. 2000. A review of Oriental Rheotanytarsus Thienemann et Bause, with descriptions of some new species (Insecta, Diptera, Chironomidae). Spixiana, 23:225-304.

Michelsen, V. 2000. Oldest authentic record of a fossil calyptrate fly (Diptera): a species of Anthomyiidae from early Coenozoic Baltic amber. Studia Dipterologica, 7:11-18.

Newman, E. 1834. Attempted division of British insects into natural orders. Entomological Magazine, 2:379431.

Pape, T., Blagoderov, V., and Mostovski, M.B. 2011. Order Diptera Linnaeus, 1758. In Zhang, Z.-Q. (ed.), Animal biodiversity: An outline of higher-level classification and survey of taxonomic richness. Zootaxa, 3148:222-229.

Sadowski, E-M., Seyfullah, L.J., Sadowski, F., Fleischmann, A., Behling, H., and Schmidt, A.R. 2015. Carnivorous leaves from Baltic amber. Proceedings of the National Academy of Sciences of the United States of America, 112:190-195. doi:10.1073/pnas.1414777111

Sæther, O.A. 1977. Female genitalia in Chironomidae and other Nematocera: morphology, phylogenies, keys. Bulletin of the Fisheries Research Board of Canada, 197:1-209.

Sæther, O.A. 1980. Glossary of chironomid morphology terminology (Diptera: Chironomidae). Entomologica scandinavica, supplement 14:1-51.

Sæther, O.A. and Kyerematen, R.A.K. 2001. Towards a phylogeny and zoogeography of the genus Rheotanytarsus Thienemann et Bause, 1913 (Diptera: Chironomidae). Tijdschrift voor Entomologie, 144:73117.

Sæther, O.A. and Spies, M. 2013. Fauna Europaea: Chironomidae. In Pape, T. and Beuk, P. (eds.) Fauna Europaea: Diptera, version 2.6.2. http:// fauna.naturkundemuseum-berlin.de/ (last update: 29 August 2013; accessed: 30 September 2015).

Säwedal, L. 1981. Amazonian Tanytarsini II. Description of Caladomyia n. gen. and eight new species (Diptera: Chironomidae). Entomologica scandinavica, 12:123-143

Seredszus, F. and Wichard, W. 2007. Fossil chironomids (Insecta, Diptera) in Baltic amber. Palaeontograph- 
ica, Beiträge zur Naturgeschichte der Vorzeit, Abteilung A: Paläozoologie - Stratigraphie, 279:49-91.

Szwedo, J. and Sontag, E. 2013. The flies (Diptera) say that amber from the Gulf of Gdańsk, Bitterfeld and Rovno is the same Baltic amber. Polish Journal of Entomology, 82:379-388. doi:10.2478/pjen-2013-0001

van der Wulp, F.M. 1858. Beschrijving van eenige nieuwe of twijfelachtige soorten van Diptera uit de familie de Nematocera. Tijdschrift voor Entomologie, 2:159-185.

van der Wulp, F.M. 1874. Dipterologische aanteekneningen. Tijdschrift voor Entomologie, 17:109-148.

Wagner, R., Hoffeins, C., and Hoffeins, H.W. 2000. A fossil nymphomyiid (Diptera) from the Baltic and Bitterfeld amber. Systematic Entomology, 25:115-120. doi:10.1046/j.1365-3113.2000.025001115.x

Zakrzewska, M. and Giłka, W. 2013. In the Eocene, the extant genus Caladomyia occurred in the Palaearctic (Diptera: Chironomidae: Tanytarsini). Polish Journal of Entomology, 82:397-403.

doi:10.2478/pjen-2013-0003

Zakrzewska, M. and Giłka, W. 2014. The oldest known chironomids of the tribe Tanytarsini (Diptera: Chironomidae) indicate plesiomorphic character states. Geobios, 47:335-343. doi:10.1016/j.geobios.2014.07.004

Zakrzewska, M. and Giłka, W. 2015a. The Tanytarsini (Diptera: Chironomidae) in the collection of the Museum of Amber Inclusions, University of Gdańsk. Zootaxa, 3946:347-360. doi:10.11646/zootaxa.3946.3.3

Zakrzewska, M. and Giłka, W. 2015b. Eonandeva gen. nov., a new distinctive genus from Eocene Baltic amber (Diptera: Chironomidae). Zootaxa, 4044:577584. doi:10.11646/zootaxa.4044.4.7

Zavřel, J. 1917. O dýchání a dýchacích ústrojích larev Chironomid. Rozpravy České Akademie Věd a Umění, Třída 2 (Mathematicko-Přirodnická), 26(3):126. 